\title{
Brain-Derived Neurotrophic Factor and Antidepressant Drugs Have Different But Coordinated Effects on Neuronal Turnover, Proliferation, and Survival in the Adult Dentate Gyrus
}

\author{
Mikko Sairanen, ${ }^{1}$ Guilherme Lucas, ${ }^{2}$ Patrik Ernfors, ${ }^{2}$ Maija Castrén, ${ }^{1}$ and Eero Castrén ${ }^{1}$ \\ ${ }^{1}$ Neuroscience Center, University of Helsinki, 00014 Helsinki, Finland, and ${ }^{2}$ Department of Medical Biochemistry and Biophysics, Karolinska Institute, \\ 17177 Stockholm, Sweden
}

\begin{abstract}
Antidepressants increase proliferation of neuronal progenitor cells and expression of brain-derived neurotrophic factor (BDNF) in the hippocampus. We investigated the role of BDNF signaling in antidepressant-induced neurogenesis by using transgenic mice with either reduced BDNF levels $\left(\mathrm{BDNF}^{+/-}\right.$) or impaired trkB activation (trkB.T1-overexpressing mice). In both transgenic strains, chronic (21 d) imipramine treatment increased the number of bromodeoxyuridine (BrdU)-positive cells to degree similar to that seen in wild-type mice $24 \mathrm{~h}$ after BrdU administration, although the basal proliferation rate was increased in both transgenic strains. Three weeks after BrdU administration and the last antidepressant injection, the amount of newborn (BrdU- or TUC-4-positive) cells was significantly reduced in both $\mathrm{BDNF}^{+-}$and trkB.T1-overexpressing mice, which suggests that normal BDNF signaling is required for the long-term survival of newborn hippocampal neurons. Moreover, the antidepressant-induced increase in the surviving BrdU-positive neurons seen in wild-type mice 3 weeks after treatment was essentially lost in mice with reduced BDNF signaling. Furthermore, we observed that chronic treatment with imipramine or fluoxetine produced a temporally similar increase in both BrdU-positive and terminal deoxynucleotidyl transferasemediated biotinylated UTP nick end-labeled neurons in the dentate gyrus, indicating that these drugs simultaneously increase both neurogenesis and neuronal elimination. These data suggest that antidepressants increase turnover of hippocampal neurons rather than neurogenesis per se and that BDNF signaling is required for the long-term survival of newborn neurons in mouse hippocampus.
\end{abstract}

Key words: imipramine; fluoxetine; BDNF; trkB; neurotrophins; TUC-4; progenitor; neurogenesis

\section{Introduction}

Antidepressant drugs have been shown to increase neurogenesis in the adult rodent hippocampus. Several different types of antidepressants, including tricyclic antidepressants, serotonin selective reuptake inhibitors, and also lithium increase neuronal proliferation in the dentate gyrus when administered chronically (Chen et al., 2000; Malberg et al., 2000). This effect is at least partially mediated by the activation of 5- $\mathrm{HT}_{1 \mathrm{~A}}$ receptors, because the deletion of 5- $\mathrm{HT}_{1 \mathrm{~A}}$ receptor abolished both proliferation and behavioral effects of fluoxetine in a novelty-suppressed feeding test (Santarelli et al., 2003). More importantly, irradiation of the hippocampus, which reduces hippocampal neurogenesis, abolishes the behavioral and proliferative effects of many different antidepressants (Santarelli et al., 2003). Furthermore, neurogenesis is reduced by stress, and antidepressant drugs counteract this

\footnotetext{
Received Sept. 9, 2004; revised Dec. 10, 2004; accepted Dec. 11, 2004

We thank Anne-Mari Haapaniemi and Laila Kaskela for excellent technical assistance, the staff of the animal house of the National Public Health Institute (Kuopio, Finland) for facilities and help, and the Sigrid Juselius Foundation and the Finnish Academy for financial support.

Correspondence should be addressed to Eero Castrén, Neuroscience Center, University of Helsinki, P.0. Box 56, 00014 Helsinki, Finland. E-mail: Eero.Castren@helsinki.fi.

DOI:10.1523/JNEUROSCI.3741-04.2005

Copyright $\odot 2005$ Society for Neuroscience $\quad$ 0270-6474/05/251089-06\$15.00/0
}

effect (Malberg et al., 2000; Czeh et al., 2001). These observations suggest that hippocampal neurogenesis may play an important role in the effects of clinical antidepressants. However, it is not clear whether this antidepressant-induced proliferation gradually leads to a net increase in granule cell number or whether the increased neurogenesis is matched by increased neuronal elimination.

Neurotrophins, particularly brain-derived neurotrophic factor (BDNF), have been implicated in the mechanism of action of antidepressant drugs (Duman et al., 1997; Altar, 1999; Nestler et al., 2002; Saarelainen et al., 2003; Castrén, 2004). Chronic but not acute antidepressant treatment upregulates the mRNA for BDNF and its receptor trkB in the hippocampus (Nibuya et al., 1995; Russo-Neustadt et al., 2000), and BDNF protein levels are increased in postmortem brain samples of depressed patients treated with antidepressants when compared with nontreated depressed patients (Chen et al., 2001). Furthermore, the activation of trkB is increased by antidepressant treatment, indicating that antidepressants enhance BDNF release in the prefrontal cortex and hippocampus (Saarelainen et al., 2003). Infusion of BDNF into the hippocampus and midbrain area produces antidepressant-like behavioral effects in rats (Siuciak et al., 1997; Shirayama et al., 2002), and transgenic mice with reduced BDNF signaling in the brain are insensitive to antide- 
pressants in behavioral tests (Saarelainen et al., 2003). Together, these data indicate that increased BDNF release and signaling are sufficient and necessary for the antidepressant effect.

BDNF signaling plays a role in the differentiation and survival of neuronal progenitor cells (Lee et al., 2002; Barnabe-Heider and Miller, 2003). Here we have studied the rate of proliferation and programmed cell death in the dentate gyrus of mice chronically injected with antidepressants and investigated the potential role of BDNF and trkB signaling in this process. Our data indicate that $\mathrm{BDNF}$ does not play a major role in antidepressant-induced neuronal proliferation but that trkB-mediated signaling is essential for the long-term survival of newborn neurons.

\section{Materials and Methods}

Animals. Heterozygote transgenic mice (background $\mathrm{CD}_{2} \mathrm{~F}_{1}=\mathrm{BALB} /$ $\mathrm{c} \times \mathrm{DBA} / 2$ ) overexpressing trkB.T1, the dominant-negative splice variant of trkB under the Thyl promoter, which directs expression in neurons (Saarelainen et al., 2000), heterozygote BDNF null mice $\left(\mathrm{BDNF}^{+/-}\right)$(Ernfors et al., 1994), and their corresponding wild-type littermates were housed in groups at $23 \pm 1^{\circ} \mathrm{C}$ with a light/dark cycle of $12 / 12 \mathrm{~h}$; mice had ad libitum access to food and water. Group sizes in the proliferation study were as follows: saline-treated group: $n=7$ for trkB.T1, $n=7$ for $\mathrm{BDNF}^{+/-}$, and $n=8$ for wild types; imipraminetreated group: $n=8$ for trkB.T1, $n=8$ for $\mathrm{BDNF}^{+/-}$, and $n=8$ for wild-types. In the survival study, the group sizes were as follows: salinetreated group: $n=6$ for trkB.T1, $n=8$ for $\mathrm{BDNF}^{+/-}$, and $n=8$ for wild-types; imipramine-treated group: $n=7$ for trkB.T1, $n=8$ for $\mathrm{BDNF}^{+/-}$, and $n=7$ for wild-types. Every experimental group consisted of an approximately equal number of male and female animals. For the fluoxetine study, wild-type NMRI mice were also used. All of the animal experiments were done in accordance with the guidelines of the Society for Neuroscience and were accepted by the experimental animal ethics committee of the University of Kuopio (Kuopio, Finland).

Treatments. Imipramine hydrochloride $\left(20 \mathrm{mg} / \mathrm{kg}_{\text {for }} \mathrm{BDNF}^{+/-}\right.$and $30 \mathrm{mg} / \mathrm{kg}$ for trkB.T1; Sigma, St. Louis, MO) and fluoxetine $(10 \mathrm{mg} / \mathrm{kg}$; Sigma) were administrated intraperitoneally once daily for 20 or $21 \mathrm{~d}$. Bromodeoxyuridine (BrdU; $50 \mathrm{mg} / \mathrm{kg}$ ) was administered intraperitoneally four times every $2 \mathrm{~h}(200 \mathrm{mg} / \mathrm{kg}$ total $)$ during the day after the last antidepressant injection (Fig. 1). At 24 and $48 \mathrm{~h}$ (proliferation study) or 21 and $22 \mathrm{~d}$ (survival study) after BrdU administration and the last imipramine injection, respectively, the animals were deeply anesthetized with pentobarbital and transcardially perfused with PBS followed by $4 \%$ paraformaldehyde (PFA/PBS). Brains were removed and postfixed in $4 \%$ PFA/PBS, cryoprotected in $20 \%$ sucrose $/ 4 \%$ PFA/PBS overnight at $+4^{\circ} \mathrm{C}$, and stored at $-70^{\circ} \mathrm{C}$. Coronal sections were sliced with a microtome (SM2000R; Leica, Nussloch, Germany) and stored at $+4^{\circ} \mathrm{C}$.

Immunohistochemistry. For BrdU detection, free-floating sections were washed, and the background was quenched with $1 \% \mathrm{H}_{2} \mathrm{O}_{2}$. DNA was denatured $\left(2 \mathrm{M} \mathrm{HCl}\right.$ for $30 \mathrm{~min}$ at $+37^{\circ} \mathrm{C} ; 0.1 \mathrm{M}$ boric acid for $10 \mathrm{~min}$ at room temperature), and sections were blocked with $5 \%$ horse serum/ $0.5 \%$ Triton X-100/PBS and incubated with the anti-BrdU antibody (1: 400; Sigma) for $48 \mathrm{~h}$ at $+4^{\circ} \mathrm{C}$, followed by a biotinylated horse antimouse IgG (1:200; Vector Laboratories, Burlingame, CA). Avidin-biotin complex (Vector Laboratories) (incubated for $45 \mathrm{~min}$ ) and DAB reaction were used to visualize the positive cells.

Newborn neurons were identified with anti-TUC-4 antibody (1:4000; Chemicon, Temecula, CA) (see below). TUC-4 immunohistochemistry was performed as described above, except that the DNA denaturation was omitted and potassium PBS was used instead of PBS. Cells undergoing apoptosis were detected with the DeadEnd colorimetric terminal deoxynucleotidyl transferase-mediated biotinylated UTP nick end labeling (TUNEL) system (Promega, Madison, WI).

Quantitation of BrdU, TUNEL, and TUC-4-positive cells was performed with Olympus Optical (Tokyo, Japan) BX50 and MicroBrightField (Colchester, VT) Stereo Investigator software. Three coronal sections randomly selected throughout the hippocampus were analyzed from every mouse, and all of the immunopositive cells in the granule cell layer of the dentate gyrus were counted.

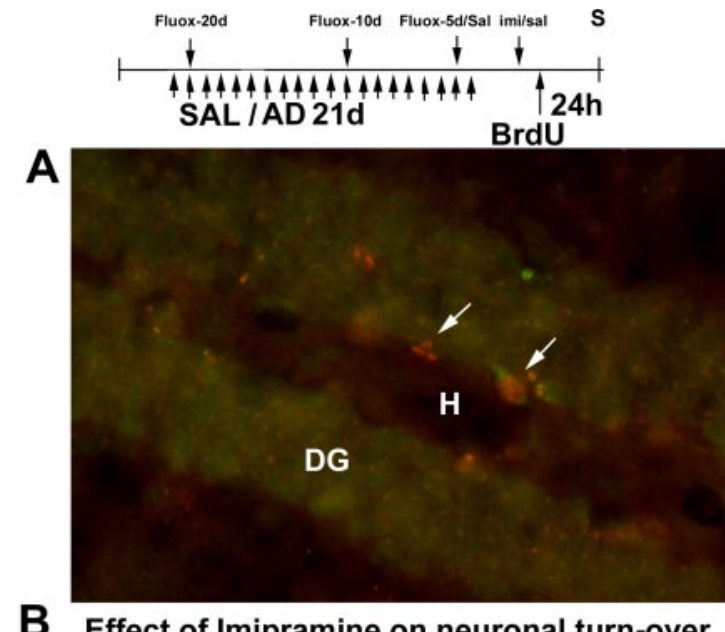

$\%$

B Effect of Imipramine on neuronal turn-over
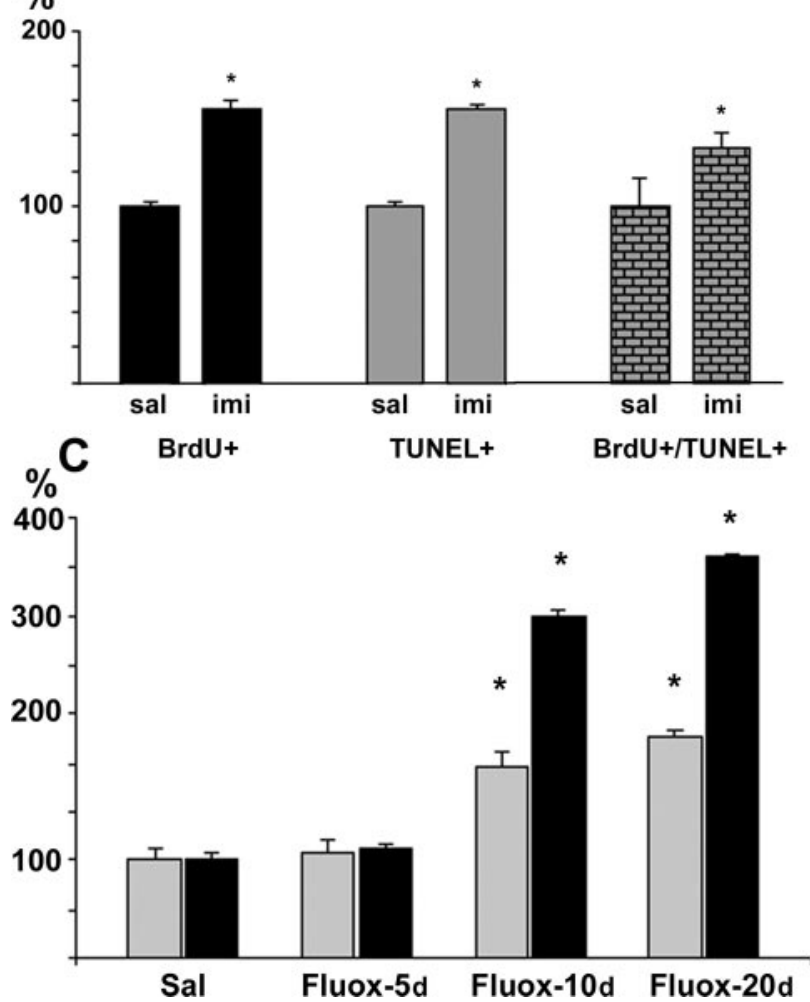

Figure 1. Antidepressants increase neuronal turnover in the dentate gyrus of the adult mouse hippocampus. Imipramine or saline was injected daily for $21 \mathrm{~d}$; saline was replaced by fluoxetine during the last 20,10, or 5 d of treatment. All mice were treated with BrdU $1 \mathrm{~d}$ before perfusion. $A$, Both BrdU-positive (left arrow) and BrdU-TUNEL double-positive cells (right arrow) are present in the dentate gyrus (DG). H, Hilus. B, Chronic imipramine treatment (30 $\mathrm{mg} / \mathrm{kg}$ ) induces a similar increase in both cell proliferation $\left(\mathrm{BrdU}^{+}\right)$and apoptosis (TUNEL) compared with saline-treated mice (sal). C, Fluoxetine (10 mg/kg) significantly increases both TUNEL-positive cells (hatched bars) and BrdU-positive cells (black bars) after 10 and $20 \mathrm{~d}$ of treatment (Fluox-10 and Fluox-20, respectively) but not after $5 \mathrm{~d}$ of treatment (Fluox-5). The apparently high response to fluoxetine $(C$ reflects a low basal-proliferation rate in the NMRI mice used in the fluoxetine experiment when compared with that in $\mathrm{CD}_{2} \mathrm{~F}_{1}$ mice used in the imipramine experiment. Error bars indicate means \pm SEM. ${ }^{*} p<0.01$ compared with the wild-type saline group. AD, Antidepressant; Fluox-20d, fluoxetine treatment for $20 \mathrm{~d}$; Fluox10d, fluoxetine treatment for $10 \mathrm{~d}$; Fluox-5d, fluoxetine treatment for $5 \mathrm{~d}$; imi, imipramine; $\mathrm{S}$, staining; SAL/Sal/sal, saline.

\section{Results}

The antidepressant-induced progenitor-cell proliferation suggests that the total number of dentate granule neurons would gradually increase during the treatment, unless the proliferation 
were matched with a comparable increase in elimination. We have compared the effects of chronic antidepressant treatment on the progenitor proliferation rate (BrdU) and apoptosis (TUNEL) in the dentate gyrus (Fig. 1A). As reported previously (Malberg et al., 2000), chronic imipramine treatment for $21 \mathrm{~d}$ produced a significant increase in BrdU-positive cells $24 \mathrm{~h}$ after BrdU administration (Fig. $1 B$ ). At the same time, imipramine treatment produced a significant and matching increase in cells labeled with TUNEL and in cells double labeled with BrdU-TUNEL in the dentate granule cell layer (Fig. $1 B$ ). A similar parallel increase in both proliferation and apoptosis was also observed when another widely used antidepressant, fluoxetine, was chronically administered (Fig. 1C). A low basal-proliferation rate in the NMRI mouse strain used in the fluoxetine experiment, when compared with that in $\mathrm{CD} 2 \mathrm{~F}_{1}$ mice used in the imipramine experiment, produced the apparently high response to fluoxetine seen in Figure $1 C$. We subsequently investigated which of the two measures, increased proliferation or apoptosis, appears first during chronic antidepressant treatment. When fluoxetine was administered for different periods of time, a temporally parallel increase in both proliferation and apoptosis was observed: the number of both BrdU- and TUNEL-positive neurons was not significantly different from control levels after $5 \mathrm{~d}$ of treatment, but a significant increase in both proliferation and apoptosis was observed after 10 and $20 \mathrm{~d}$ of fluoxetine treatment (Fig. 1C). Our data are consistent with the idea that antidepressant treatment increases turnover of dentate granule neurons rather than proliferation per se and that the proliferation and apoptosis are regulated simultaneously and coordinately.

Neurotrophins act as target-derived survival factors during the development of the peripheral nervous system. Antidepressant treatment is known to increase the production of BDNF in the dentate granule neurons as well as in their target neurons in the CA3 area (Russo-Neustadt et al., 2000). Here we have investigated the role of BDNF and its receptor trkB in antidepressantinduced hippocampal neurogenesis. Imipramine was chronically administered for $21 \mathrm{~d}$ to wild-type mice and $\mathrm{BDNF}^{+/-}$mice, which have approximately one-half the normal BDNF levels in the brain (Ernfors et al., 1994) or to transgenic mice overexpressing the dominant-negative trkB isoform (trkB.T1), which show reduced trkB activation in the brain (Saarelainen et al., 2000); $\mathrm{BrdU}$ was injected $24 \mathrm{~h}$ after the last imipramine injection. To estimate the rate of neurogenesis, anti-BrdU staining was performed $24 \mathrm{~h}$ after BrdU administration (Fig. $2 \mathrm{~A}$ ). In the wild-type mice, imipramine significantly increased cell proliferation in the dentate gyrus $24 \mathrm{~h}$ after BrdU injections (Fig. 2D,F,G). Unexpectedly, both types of transgenic mice showed increased baseline cell proliferation when compared with the saline-injected wild-type mice (Fig. $2 F, G$ ). Nevertheless, imipramine produced an additional increase in cell proliferation in both $\mathrm{BDNF}^{+/-}$mice (Fig. $2 F$ ) and trkB.T1 mice (Fig. $2 E, G$ ) that was of the same magnitude as that observed in the wild-type mice (the ratio of saline over imipramine treatment was not significantly different between genotypes). These data suggest that BDNF and trkB activation do not play a major role in the antidepressant-induced increase in the proliferation of neuronal progenitor cells.

Newborn cells have several fates: some cells survive and differentiate into neurons or glia, whereas others die. In the peripheral nervous system, neurotrophins do not play a major role in the proliferation of neuronal precursors but are critical for the survival of newly born neurons. We have therefore assessed the role of BDNF signaling in the long-term survival of newborn neurons induced by antidepressant treatment using BrdU and
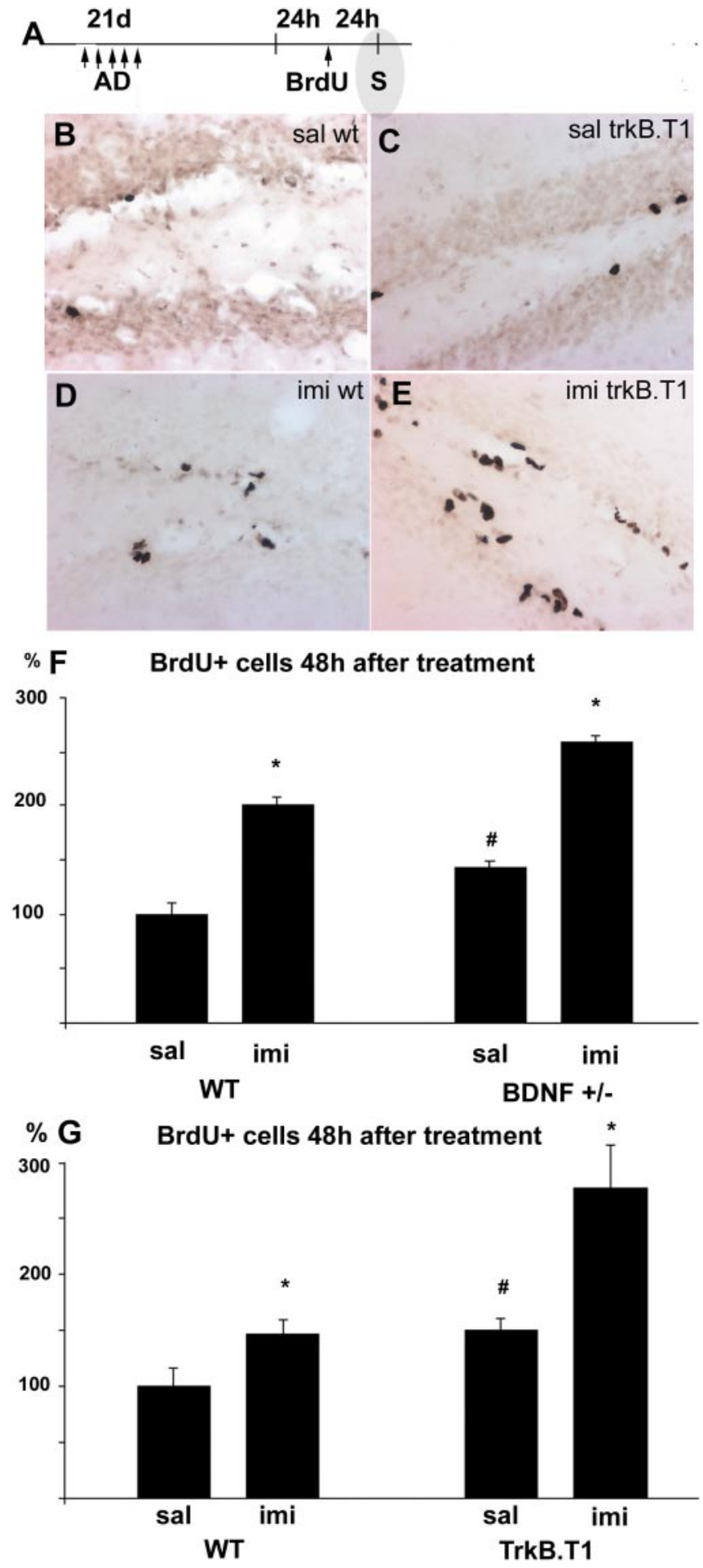

Figure 2. Chronic antidepressant treatment increases the number of BrdU-positive cells in the adult hippocampus. $A$, Mice treated with imipramine [antidepressant (AD); $30 \mathrm{mg} / \mathrm{kg}$ ] daily for $21 \mathrm{~d}$ received BrdU injections $24 \mathrm{~h}$ after the last imipramine injection and were prepared for staining (S) $24 \mathrm{~h}$ after the last BrdU injection. Immunohistochemical staining shows BrdUlabeled cells in the granule cell layer of the dentate gyrus in saline-treated wild-type mice $(B)$, saline-treated trkB.T1 transgenic mice $(C)$, imipramine-treated wild-type mice $(D)$, and imipramine-treated trkB.T1 transgenic mice (E). imi, Imipramine; sal, saline; wt, wild type. Magnification in $B-E$ is $200 \times$. F, G, Quantitative analysis of the BrdU-labeled cells in the granule cell layer of the dentate gyrus $24 \mathrm{~h}$ after BrdU injections. Imipramine produced a significant and similar increase in cell proliferation in all genotypes: wild-type mice (WT; $F, G), B^{2} \mathrm{NF}^{+/-}$ mice $(F)$, and trkB.T1 transgenic mice $(G)$. The basal-proliferation rate was increased in both $\mathrm{BDNF}^{+1-}$ and trkB.T1 mice compared with controls $(F, G)$. Error bars indicate means \pm SEM. ${ }^{*} p<0.01$, saline versus imipramine; ${ }^{\#} p<0.05$, wild-type versus transgenic mice. 

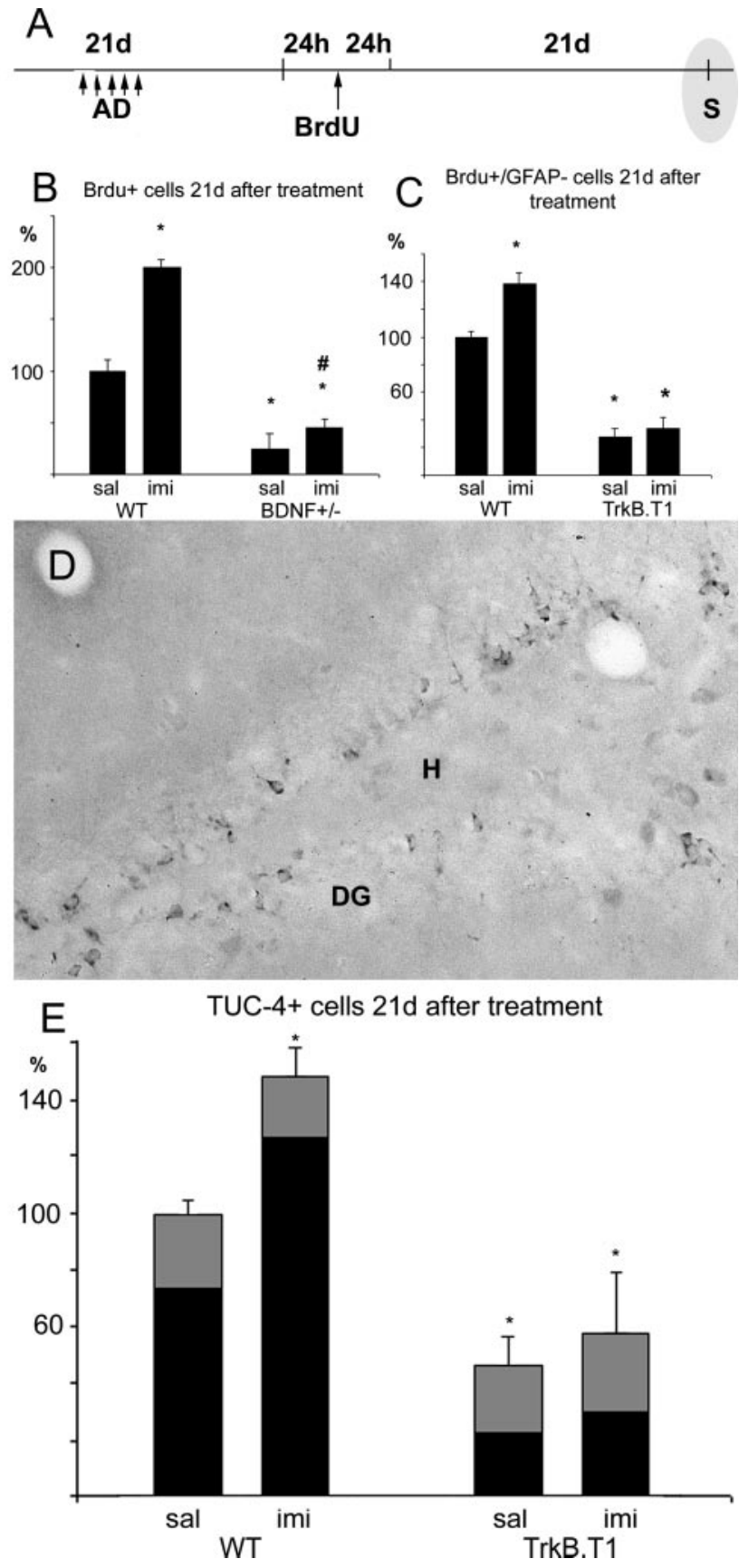

Figure 3. Normal BDNF signaling is required for the survival of newborn neurons after chronic antidepressant treatment. $A$, The number of BrdU-positive cells was determined 21 and $22 \mathrm{~d}$ after BrdU administration and the last imipramine injection [antidepressant (AD)], respectively. S, Staining. $B, C, E$, The number of surviving cells was significantly reduced in the hippocampus of both $\mathrm{BDNF}^{+/-}$mice (BrdU-positive cells) and trkB.T1 transgenic mice (C, BrdUpositive/GFAP-negative cells; E, TUC-4-positive neurons) (also see supplementary Fig. 4, available at www.jneurosci.org as supplemental material). The positive effect of imipramine on cell proliferation is maintained for 3 weeks in wild-type mice $(B, C, E)$ and $B D N F^{+/-}$transgenic mice $(B)$. D, TUC-4 staining was used as a marker to identify newborn neurons. DG, Dentate gyrus; H, hilus. $E$, Bar height indicates TUC-4-positive cells, the black portion of each bar denotes BrdU/TUC-4 double-positive cells. Error bars indicate means \pm SEM. ${ }^{*} p<0.01$ compared with the wild-type saline group; ${ }^{\#}<0.01$ compared with the saline-treated group in the same genotype. imi, Imipramine; sal, saline; WT, wild type.

TUC-4 stainings (Fig. 3A). TUC-4 is expressed immediately after neuronal birth in the growth cones and was used as a marker for newly born neurons (Quinn et al., 1999). Three weeks after the cessation of chronic imipramine treatment and BrdU adminis- tration, $52.7 \%$ of the BrdU-labeled cells were alive in wild-type mice when compared with the labeled cells $24 \mathrm{~h}$ after BrdU treatment, which is consistent with previous observations (Kempermann et al., 1997; Malberg et al., 2000). In the imipramine-treated wild-type animals, the number of BrdU- and TUC-4-positive cells was significantly higher than in the saline-injected wild-type mice (Fig. $3 B, C, E)$, indicating that the proliferation-inducing effect of imipramine was maintained for at least $21 \mathrm{~d}$ after treatment in wild-type mice, as also shown previously (Malberg et al., 2000).

In the $\mathrm{BDNF}^{+/-}$mice, the number of BrdU-positive cells was significantly decreased 3 weeks after BrdU injection when compared with the wild-type mice, indicating that normal BDNF levels are essential for the long-term survival of the newborn granule neurons (Fig. 3B). A similar kind of reduction in the long-term survival of the newly born neurons was also observed in trkB.T1-overexpressing mice when the number of cells positive for BrdU but negative for GFAP (Fig. 3C and supplementary Fig. 4, available at www.jneurosci.org as supplemental material) or the number of TUC-4-positive or BrdU/TUC-4 doublepositive neurons was counted (Fig. $3 D, E$ ). These data indicate that dentate granule neurons are dependent on BDNF and trkB activity for their survival. Although the source for the critical BDNF remains to be determined [BDNF is expressed and induced by antidepressants both in the granule neurons themselves as well as in the CA3 target neurons (Russo-Neustadt et al., 2000)], these data are consistent with the notion that, as in the developing peripheral nervous system, granule neurons are dependent on BDNF released by their target, the dendrites of the CA3 pyramidal neurons.

In contrast to the significant increase in BrdU-positive surviving neurons found in the hippocampus of wild-type mice 3 weeks after antidepressant treatment (Fig. 3B,C,E), only a modest increase in surviving neurons could be observed in antidepressanttreated mice with compromised BDNF signaling. The antidepressant effect was small but significant in the $\mathrm{BDNF}^{+/-}$mice (Fig. 3), but no significant effect was observed in the trkB.T1 mice (Fig. 3C,E). These data indicate that antidepressant treatment is not able to support an increased level of newborn neurons over a long period of time if the normal trkB signaling is inhibited. Together, these data indicate that antidepressants have two different types of effects on the dentate granule cells: a proliferative effect that is independent of neurotrophins and a survival promoting effect that requires BDNF and trkB activation.

In the trkB.T1-overexpressing mice, the number of BrdUpositive cells alive $21 \mathrm{~d}$ after BrdU injection was found to be higher in the saline-treated transgenic mice than in the imipramine-treated transgenic mice (supplementary Fig. 4, available at www.jneurosci.org as supplemental material). A double-labeling study with BrdU and GFAP, an astrocytic marker (supplementary Fig. 4, available at www.jneurosci.org as supplemental material), revealed that this dramatic difference between the treatment groups in transgenic mice was attributable to the fact that the major portion of the BrdU-labeled cells in the salinetreated trkB.T1 animals were GFAP-positive glia cells, whereas only a minority of BrdU-positive cells in the imipramine-treated transgenic mice were also positive for GFAP (supplementary Fig. 4, available at www.jneurosci.org as supplemental material). When the portion of BrdU/GFAP double-positive cells was removed from the total number of BrdU-positive cells, the number of remaining cells (Fig. $3 C$ ) corresponded to the number of neurons as revealed by TUC-4 staining in the same mice (Fig. $3 E$ ), as well as to that observed in $\mathrm{BDNF}^{+/-}$mice (Fig. $3 B$ ). Additional studies will be needed to clarify why chronic imipramine treat- 
ment dramatically reduced the number of BrdU/GFAP doublepositive cells in trkB.T1-overexpressing mice (supplementary Fig. 1, available at www.jneurosci.org as supplemental material), an effect that was not seen in $\mathrm{BDNF}^{+/-}$mice.

\section{Discussion}

The data presented in this paper suggest that the effects of antidepressants on hippocampal neurogenesis involve two separate processes: increased proliferation of progenitor cells and efficient survival of newborn neurons. Antidepressant treatment increased neuronal progenitor-cell proliferation to a similar degree in both wild-type mice and in two transgenic strains of mice with reduced BDNF signaling, trkB.T1-overexpressing mice and $\mathrm{BDNF}^{+/-}$mice. These data indicate that the proliferation phase is not regulated by neurotrophins but is regulated by other effects, most likely involving the increase in extracellular levels of serotonin and norepinephrine (Gould, 1999; Kulkarni et al., 2002; Santarelli et al., 2003). In contrast, our data suggest that the longterm survival on the newly born neurons appears to require functional BDNF signaling (Lee et al., 2002), as has also been reported in vitro (Barnabe-Heider and Miller, 2003). Newborn neurons, after exiting the cell cycle and committing to a neuronal fate, migrate into the granule cell layer, grow a dendritic tree, target an axon into the mossy fiber pathway toward the CA3 area, and establish functional afferent and efferent connections before they can be expected to contribute to the function of the hippocampus. These processes have been estimated to take several days or weeks to develop (van Praag et al., 2002), a time that compares favorably with the delay of the clinical effects of antidepressants. BDNF, which is regulated by neuronal activity in the brain, may play a crucial role in the activity-dependent selection of functionally active newly born neurons through enhanced survival.

Our data are consistent with a role for BDNF in the adult dentate gyrus that is similar to the classical role of neurotrophins in the developing peripheral nervous system. Although neurotrophins do not appear to have a major role in the proliferation of sensory and sympathetic neurons in the paravertebral ganglia, target-derived neurotrophins are critical survival factors in the selection of peripheral neurons at the time when they have differentiated and reached their target tissue (Levi-Montalcini, 1987; Barde, 1989; Huang and Reichardt, 2001). A similar kind of target-derived role for neurotrophins has been postulated in the developing axon branches and synapses in the brain; however, in the CNS, the release of neurotrophins is activity dependent and requires active stimulation by the innervating axon (Poo, 2001; Cohen-Cory, 2002). We show here that although the inhibition of neurotrophin signaling did not influence the ability of antidepressants to increase the proliferation of hippocampal neuronal progenitor cells, the long-term survival of the newborn neurons is reduced when BDNF release or trkB activity is reduced. These data are consistent with a role for BDNF as a target-derived survival factor for the newly born neurons in the dentate gyrus.

Here we provide evidence that apoptosis is increased in the dentate gyrus of normal rodents to the same extent as the neuronal proliferation after a long-term antidepressant treatment. Both proliferation rate and apoptosis were increased with a similar temporal profile, which suggests the existence of a homeostatic mechanism that keeps the number of dentate granule neurons constant over time. Moreover, our observation that neurogenesis is increased in two different models of compromised BDNF function at the same time that the survival of neurons is reduced is also consistent with a homeostatic regulation of hippocampal neuronal proliferation and elimination. In stress and depression, where the total number of granule cells may be reduced (McEwen, 1999; Czeh et al., 2001), antidepressants may lead to an initial increase in the total number of cells, but over time this increasing effect may be balanced by increased apoptosis to maintain normal amounts of neurons. Although apoptosis was increased by antidepressant treatments, the number of BrdU-positive neurons surviving for 3 weeks in the mice deficient in BDNF signaling remained enhanced in the antidepressanttreated group. This observation suggests that, in addition to the newborn neurons, the elimination of the existing granule neurons is also enhanced as more newborn cells enter the scene. Thus, antidepressant treatment, at least in the normal rodent hippocampus, increases the turnover of dentate granule neurons rather than their total number.

It may appear paradoxical that antidepressant treatment that increases hippocampal BDNF, the putative target-derived survival factor for the granule neurons, leads to increased apoptosis of these very cells. It should be emphasized, however, that the role of BDNF in the developing nervous system is not to indiscriminately support survival of any neuron but to select out those neurons that have made the best contact with their target cells (Barde, 1989). In the CNS, activity-dependent BDNF release selects out those neurons and connections that mediate useful neuronal activity to the target neuron (Thoenen, 1995) and helps to eliminate connections that produce random noise. Therefore, although antidepressant-induced neurogenesis increases overall activity and therefore BDNF expression in the CA3 target neurons, only those neurons that best mediate useful neuronal activity to the target are selected and prevail in the competition. Increased granule neuron turnover produced by antidepressant treatments indicates that there are more competing neurons available for selection, which may improve the ability of the hippocampus to rapidly adapt to emerging environmental challenges. It is of interest to determine whether this improved adaptability produced by enhanced granule neuron turnover might play a role in the clinically beneficial effect of antidepressant treatments.

\section{References}

Altar CA (1999) Neurotrophins and depression. Trends Pharmacol Sci 20:59-61.

Barde Y-A (1989) Trophic factors and neuronal survival. Neuron 2:1525-1534.

Barnabe-Heider F, Miller FD (2003) Endogenously produced neurotrophins regulate survival and differentiation of cortical progenitors via distinct signaling pathways. J Neurosci 23:5149-5160.

Castrén E (2004) Neurotrophic effects of antidepressant drugs. Curr Opin Pharmacol 4:58-64.

Chen B, Dowlatshahi D, MacQueen GM, Wang JF, Young LT (2001) Increased hippocampal BDNF immunoreactivity in subjects treated with antidepressant medication. Biol Psychiatry 50:260-265.

Chen G, Rajkowska G, Du F, Seraji-Bozorgzad N, Manji HK (2000) Enhancement of hippocampal neurogenesis by lithium. J Neurochem 75:1729-1734.

Cohen-Cory S (2002) The developing synapse: construction and modulation of synaptic structures and circuits. Science 298:770-776.

Czeh B, Michaelis T, Watanabe T, Frahm J, de Biurrun G, van Kampen M, Bartolomucci A, Fuchs E (2001) Stress-induced changes in cerebral metabolites, hippocampal volume, and cell proliferation are prevented by antidepressant treatment with tianeptine. Proc Natl Acad Sci USA 98:12796-12801.

Duman RS, Heninger GR, Nestler EJ (1997) A molecular and cellular theory of depression. Arch Gen Psychiatry 54:597-606.

Ernfors P, Lee KF, Jaenisch R (1994) Mice lacking brain-derived neurotrophic factor develop with sensory deficits. Nature 368:147-150.

Gould E (1999) Serotonin and hippocampal neurogenesis. Neuropsychopharmacology 21:46S-51S. 
Huang EJ, Reichardt LF (2001) Neurotrophins: roles in neuronal development and function. Annu Rev Neurosci 24:677-736.

Kempermann G, Kuhn HG, Gage FH (1997) More hippocampal neurons in adult mice living in an enriched environment. Nature 386:493-495.

Kulkarni VA, Jha S, Vaidya VA (2002) Depletion of norepinephrine decreases the proliferation, but does not influence the survival and differentiation, of granule cell progenitors in the adult rat hippocampus. Eur J Neurosci 16:2008-2012.

Lee J, Duan W, Mattson MP (2002) Evidence that brain-derived neurotrophic factor is required for basal neurogenesis and mediates, in part, the enhancement of neurogenesis by dietary restriction in the hippocampus of adult mice. J Neurochem 82:1367-1375.

Levi-Montalcini R (1987) The nerve growth factor: thirty-five years later. EMBO J 6:1145-1154.

Malberg JE, Eisch AJ, Nestler EJ, Duman RS (2000) Chronic antidepressant treatment increases neurogenesis in adult rat hippocampus. J Neurosci 20:9104-9110.

McEwen BS (1999) Stress and hippocampal plasticity. Annu Rev Neurosci 22:105-122.

Nestler EJ, Barrot M, DiLeone RJ, Eisch AJ, Gold SJ, Monteggia LM (2002) Neurobiology of depression. Neuron 34:13-25.

Nibuya M, Morinobu S, Duman RS (1995) Regulation of BDNF and trkB mRNA in rat brain by chronic electroconvulsive seizure and antidepressant drug treatments. J Neurosci 15:7539-7547.

Poo MM (2001) Neurotrophins as synaptic modulators. Nat Rev Neurosci 2:24-32.

Quinn CC, Gray GE, Hockfield S (1999) A family of proteins implicated in axon guidance and outgrowth. J Neurobiol 41:158-164.

Russo-Neustadt AA, Beard RC, Huang YM, Cotman CW (2000) Physical activity and antidepressant treatment potentiate the expression of specific brain-derived neurotrophic factor transcripts in the rat hippocampus. Neuroscience 101:305-312.

Saarelainen T, Lukkarinen JA, Koponen S, Gröhn OH, Jolkkonen J, Koponen E, Haapasalo A, Alhonen L, Wong G, Koistinaho J, Kauppinen RA, Castrén E (2000) Transgenic mice overexpressing truncated trkB neurotrophin receptors in neurons show increased susceptibility to cortical injury after focal cerebral ischemia. Mol Cell Neurosci 16:87-96.

Saarelainen T, Hendolin P, Lucas G, Koponen E, Sairanen M, MacDonald E, Agerman K, Haapasalo A, Nawa H, Aloyz R, Ernfors P, Castrén E (2003) Activation of the TrkB neurotrophin receptor is induced by antidepressant drugs and is required for antidepressant-induced behavioral effects. J Neurosci 23:349-357.

Santarelli L, Saxe M, Gross C, Surget A, Battaglia F, Dulawa S, Weisstaub N, Lee J, Duman R, Arancio O, Belzung C, Hen R (2003) Requirement of hippocampal neurogenesis for the behavioral effects of antidepressants. Science 301:805-809.

Shirayama Y, Chen AC, Nakagawa S, Russell DS, Duman RS (2002) Brainderived neurotrophic factor produces antidepressant effects in behavioral models of depression. J Neurosci 22:3251-3261.

Siuciak JA, Lewis DR, Wiegand SJ, Lindsay RM (1997) Antidepressant-like effect of brain-derived neurotrophic factor (BDNF). Pharmacol Biochem Behav 56:131-137.

Thoenen H (1995) Neurotrophins and neuronal plasticity. Science 270:593-598.

van Praag H, Schinder AF, Christie BR, Toni N, Palmer TD, Gage FH (2002) Functional neurogenesis in the adult hippocampus. Nature 415:10301034. 